\title{
GRINDABILITY OF SELECTED GRADES OF LOW-ALLOY HIGH-SPEED STEEL
}

\author{
Jan Jaworski' ${ }^{1}$ Rafał Kluz' ${ }^{1}$, Tomasz Trzepieciński²
}

1 Department of Manufacturing and Production Engineering, The Faculty of Mechanical Engineering and
Aeronautics, Rzeszów University of Technology, Al. Powstańców Warszawy 8, 35-959 Rzeszów, Poland, e-mail:
jjktmiop@prz.edu.pl, rkktmiop@prz.edu.pl
2 Department of Material Forming and Processing, The Faculty of Mechanical Engineering and Aeronautics,
Rzeszów University of Technology, Al. Powstańców Warszawy 8, 35-959 Rzeszów, Poland, e-mail: tomtrz@prz.
edu.pl

Received: 2016.06.02

Accepted: 2016.07.04

Published: 2016.09.01

\begin{abstract}
In this paper, we presents the results of investigations studied the cutting ability and grindability of selected high-speed steels. We analysed the effect of the austenitization temperature on the grain size, the amount of retained austenite and percentage of retained austenite in HS3-1-1 steel. Furthermore, the investigations concerned on the efficiency of the keyway broaches during the whole period of operation were carried out. It was found that the value of average roughness parameter increases together with increases in the grinding depth. The investigations also show the influence of tempering conditions on the volume of carbide phases in HS3-1-1 steel.
\end{abstract}

Keywords: austenitization, cutting ability, high-speed steel, tool wear.

\section{INTRODUCTION}

The term "grindability" is defined as the ease with which a material can be ground to a specification or to meet criteria when manufacturing a finished product from raw material [2]. Loss of cutting ability of abrasive tools or a change in their original shape affects the quality of the surface finish and dimensional accuracy of sharpened tools. For this reason, abrasive tool wear is the primary criterion of evaluation of the grindability of the workpiece, which consequently has a decisive influence on the lifespan of grinding tools [9]. Loss of tool life under cutting is caused by wheel burns on the surface of the tool point, which are formed during tool sharpening. High grinding temperatures facilitate the formation of an increased amount of retained austenite on the surface layer of high-speed steel [7]. This reduces tool life under cutting. Therefore, the possibility of the appearance of these defects should be excluded by the choice of adequate sharpening parameters.
Currently, a large number of works is devoted to the problems of forecasting tool life and diagnostics of cutting process [8]. This is particularly important in the case of simultaneous multiple tool cutting. In the multitooling process the requirements of quality and reliability of tools are especially signifficant [18]. It is emphasized that both the increase in the cost of tool wear per unit of product and tool costs can range from $3-5 \%$ of all costs necessary to manufacture the product. However, so far the evaluation of efficiency of tools operating remains a complex and current issue.

There is an increase in requirements for cutting materials which must provide high productivity and reliability of the cutting tool. Low-alloy high-speed steels (LAHSSs) are a subgroup of high-speed steels with a content of $\% \mathrm{~W}+$ $1.5 \% \mathrm{Mo}<12 \%$. Reductions in molybdenum and tungsten levels which may be achieved by increasing the nitrogen level of LAHSSs could have significant technical and economic benefit. In the development of LAHSSs the tendency to 
the total level of alloying components content restriction is observed. The properties of LAHSSs correspond to normal productivity of typical high-speed steels [12].

The wear of tools is one of the most important characteristics defining the accuracy of the technological system of part machining [4, 14]. The prediction and control of wear is one of the most essential problems emerging in the design of cutting operations $[11,16]$. The wear resistance of the LAHSS tool material influences the tool's durability $[6,13]$.

The efficiency of tool operation depends on the properties of the blade material, its construction and physical processes proceed in the contact zone of the blade and the workpiece. To determine the area of application of tools made of any grades of LAHSSs and the selection of optimum values of cutting parameters, it is necessary to study the effect of machining conditions on cutting force and average roughness [5]. Furthermore, the effect of the austenitization temperature on grain size, the amount of retained austenite and percentage of retained austenite decided on the durability of a tool. All the major material properties such strength and hardness are known to depend upon grain size and conditions of heat treatment. Moreover, during processing grain size plays a pivotal role in the development of eventual microstructure due to recrystallization, grain growth and phase transformations [3]. Knowing mentioned phenomena, we can determine the basic causes of the tool wear depending on the specific working conditions and suggest the most effective ways to increase its durability. It is the purpose of this paper to explore these phenomena.

\section{CUTTING ABILITY AND GRINDABILITY OF HS3-1-1 STEEL}

In the case of cutting tools cutting ability is determined primarily by such material properties as hardness, strength and temperability. These properties of the tool material at a relatively wide range can be adjusted by suitable selection of parameters of heat treatment. The optimum parameters of heat treatment ensure simultaneously the highest hardness, strength and temperability [3]. Determination of the optimal austenitization temperature requires special attention, because it regulates a number of important processes. Firstly, the increase of the austenitization temperature causes higher dissolution of secondary carbides and also increases temperability, hardness and strength of the material. Secondly, when material is heated to too high temperature the excessive growth of grain exists and residual austenite content increases. A small carbon content can influence the formation of ferrite or even partial melting of the grain boundaries.

It is known that steels with small amount of alloying elements are exposed to overheating of the material during the austenitization . The lack of alloying elements can be partially filled up by addition of titanium and niobium. The reduction of steel hardness at of 2-4 HRC is associated with the deterioration of ductility and strength, and an increase in both the value of friction coefficient and abrasion resistance. Therefore, the LAHSS should be used in a state of high hardness, which is connected with the determination of the optimum temperatures of austenitization and tempering.

Austenitization temperature used for the preparation of a high-quality tool should ensure:

- a grain size measured using Snyder-Graph method not less than $10 \mu \mathrm{m}$,

- the bending strength should be $2500-3000 \mathrm{MPa}$,

- impact strength should be above $4 \cdot 10^{5} \mathrm{~J} / \mathrm{m}^{2}$,

- hardness of 63.5-64 HRC.

\section{MATERIALS AND METHOD}

The samples with dimensions of $6 \times 6 \times 65 \mathrm{~mm}$ were made of low-alloy high-speed steels (Table 1). The heat treatment was carried out according

Table 1. Low-alloy high-speed steel grades: chemical constitution and hardness

\begin{tabular}{|c|c|c|c|c|c|c|c|}
\hline \multirow{2}{*}{ Steel grade } & \multirow{2}{*}{ Hardness (HRC) } & \multicolumn{7}{|c|}{ Chemical constitution (wt\%). } \\
\cline { 3 - 8 } & & $\mathrm{C}$ & $\mathrm{W}$ & Mo & $\mathrm{Cr}$ & $\mathrm{V}$ & $\mathrm{Si}$ \\
\hline HS3-3-3 & 64 & 1.00 & 2.98 & 2.83 & 4.27 & 2.30 & - \\
\hline HS2-5-2 & 64 & 0.99 & 1.67 & 4.79 & 3.78 & 1.15 & - \\
\hline HS3-1-1 & $63-68$ & 1.11 & 3.35 & 1.15 & 4.65 & 1.75 & 2.05 \\
\hline HS6-5-2 & 64 & 0.82 & 5.55 & 5.13 & 4.27 & 2.06 & - \\
\hline
\end{tabular}



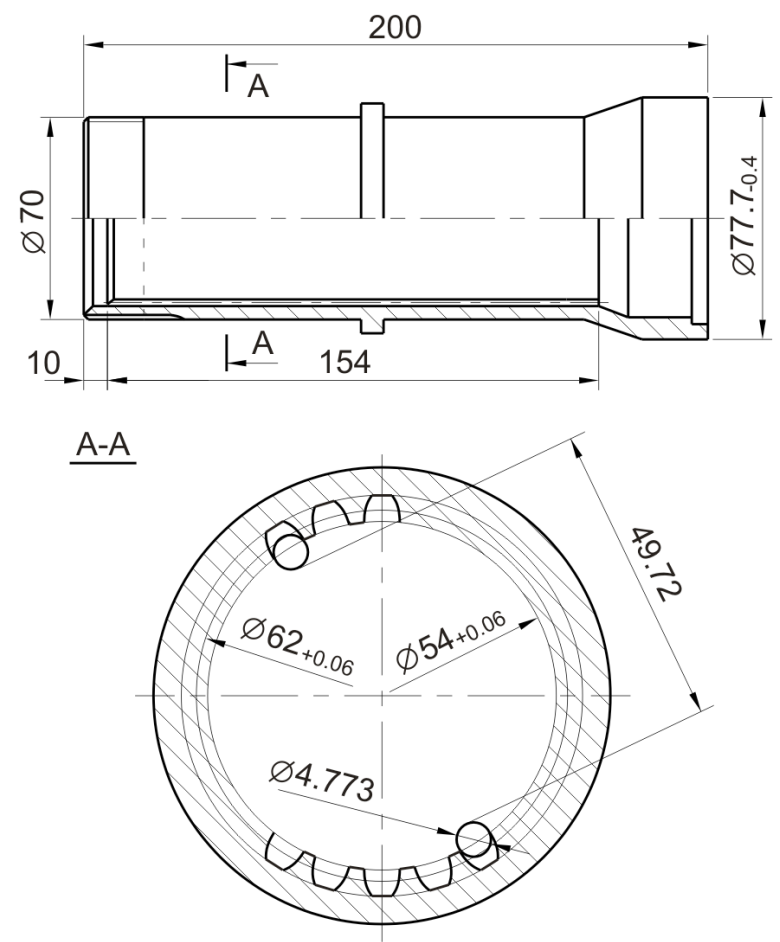

Fig. 1. Spline sleeve of Cardan shaft made of $\mathrm{C} 45$ steel (HB 255 $\div 310$, module pitch $\mathrm{M}=2,5$, a number of splines $Z=22$ )

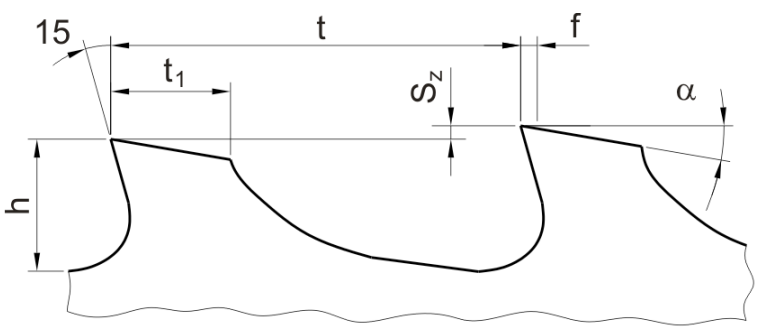

Fig. 2. Geometry of the teeth of keyway broach

to recommendation by suitable standards. The investigations were carried out on a flat-surface grinder with a 95A24K disk-type grinding wheel without cooling. The influence of the grinding parameters was defined especially for the surface roughness and a coefficient of grinding with a large range of grinding parameters: $\mathrm{v}_{\mathrm{c}}=20 \mathrm{~m} / \mathrm{s}$, $a_{p}=0.005-0.035 \mathrm{~mm}$, and $\mathrm{v}_{\mathrm{f}}=2-6 \mathrm{~m} / \mathrm{min}$, without cross-feed on the whole width of the sample. After each study, the disk-type grinding wheel was honed by diamond honing. The forces were measured using a dynamometer, whereas the roughness of the surface was measured using the Surtronic 3+ profilograph. Grain size was evaluated by Snyder-Graff method.

In the process of operation the keyway broaches are subjected to repeated sharpening and overhaul life of sharpened tools ranges from $75-85 \%$ of the total overhaul life of work broach. Therefore, the investigations concerned on efficiency of the keyway broaches during the whole period of operation were carried out. The experimental tests were performed during pull broaching of the spline sleeve of the shaft (Fig. 1) made of C45 steel.

On the basis of received results and their analysis the graphs presented the effect of sharpening of the tool face on the total and the average size of tooth wear VB at the same number of machined parts were prepared. The required quality of machined surface during machining of the spline sleeve was obtained with an assumed criterion of the keyway broach wear in the range of $0.3-0.4 \mathrm{~mm}$. The general broach tool geometry and the values of the geometrical parameters of the broach teeth are shown in figure 2 and table 2 , respectively.

\section{RESULTS AND DISCUSSION}

\section{Effect of grinding depth}

The results of the cutting forces $\mathrm{P}_{\mathrm{y}}$ and $\mathrm{P}_{\mathrm{z}}$ in dependence on the depth of grinding and longitudinal feed are shown in Figure 3. The value of

Table 2. Values of geometrical parameters of the teeth of keyway broach

\begin{tabular}{|c|c|c|c|c|c|c|c|}
\hline No. of tooth $z$ & $\mathrm{Sz}, \mathrm{mm}$ & $\alpha,{ }^{\circ}$ & $\mathrm{f}, \mathrm{mm}$ & $\mathrm{t}, \mathrm{mm}$ & $\mathrm{t} 1, \mathrm{~mm}$ & $\mathrm{~h}, \mathrm{~mm}$ & $\begin{array}{c}\text { Outer diameter } \\
\mathrm{D}, \mathrm{mm}\end{array}$ \\
\hline $1 \div 2$ & 0.15 & \multirow{3}{*}{3} & \multirow{7}{*}{0.05} & 16 & 5 & 5 & \multirow{7}{*}{33.5} \\
\hline $3 \div 4$ & \multirow{2}{*}{0.35} & & & \multirow{7}{*}{22} & \multirow{7}{*}{6} & \multirow{7}{*}{7} & \\
\hline $5 \div 6$ & & & & & & & \\
\hline $7 \div 14$ & 0.06 & \multirow{3}{*}{2} & & & & & \\
\hline 15 & 0.015 & & & & & & \\
\hline 16 & 0.01 & & & & & & \\
\hline $17 \div 18$ & 0.002 & \multirow{2}{*}{1} & & & & & \\
\hline $19 \div 25$ & 0.002 & & $0.1 \div 0.6$ & & & & 38.1 \\
\hline
\end{tabular}




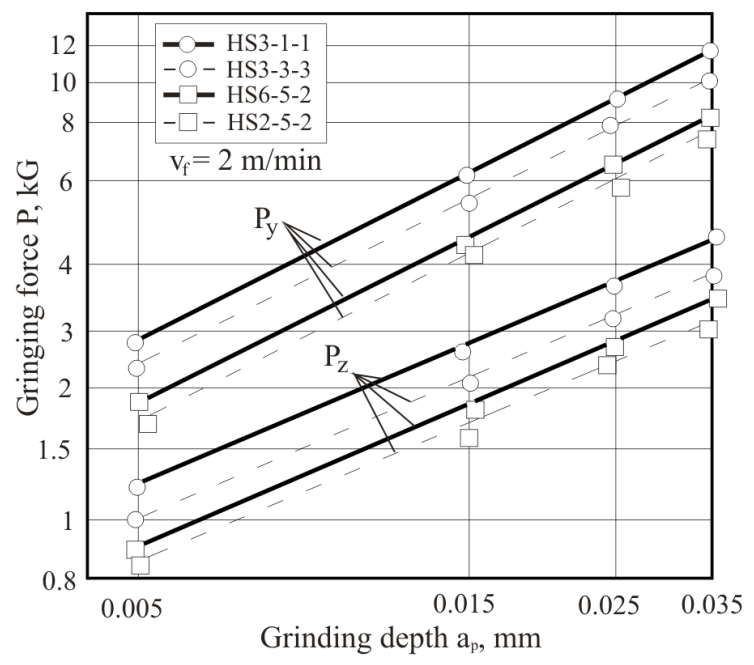

Fig. 3. Effect of grinding depth on the value of grinding forces

the cutting force increases with increases in the values of longitudinal feed and cutting depth. The smallest value of cutting forces was registered during grinding of HS2-5-2 and HS6-5-2 steels. In contrast, the largest grinding forces were found for HS3-3-3 and HS3-1-1 steels. The fact that the cutting forces in grinding of HS3-1-1 steel are greater than in the case of grinding of HS3-3-3 steel, although the former contains a lower vanadium content, can be explained by the higher content of carbon in the HS3-3-3 steel [15].

From the point of view of the quality of the surface layer, to increase the efficiency of sharpening, it is better to increase the lengthwise feed than the grinding depth. Ultimate stresses on the surface layer were not investigated. It is known that their source is the temperature gradient on the machined surface layer. It can be assumed that for HS3-1-1 steel the level of stresses will be a little higher than for HS6-5-2 steel. When the research was completed and samples were checked, it was determined that the level of ultimate stresses did not lead to the formation of grinding cracks.

The research results confirm the higher propensity to structural modifications of HS3-1-1 steel during grinding. The surface roughness is a very important parameter of machined surface quality. The results of the measure of the Ra parameter are presented in figure 4. Ra parameter value increases with increasing grinding depth and lengthwise feed in each case. In the research, the differences in surface finish do not have an impact on the machinability of tools.

An increase in wear velocity with increasing grinding depth is observed. This can be explained

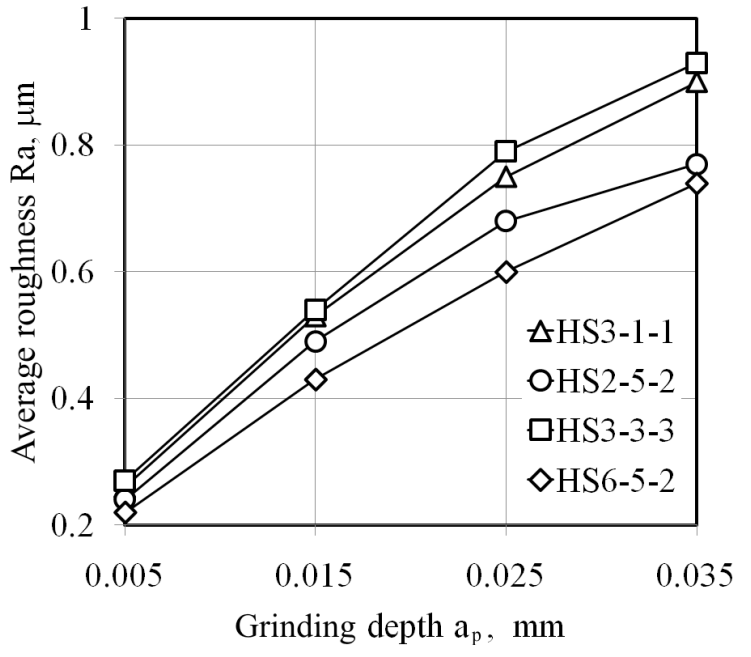

Fig. 4. Effect of the cutting depth on the average roughness value

as an increase of damage during sharpening of the surface layer of high-speed steel as a result of the large amount of retained austenite. Studies on the form of wear of grinding wheels [1] make it clear that their wear is primarily dependent on the properties of the workpiece, the abrasive used, cutting forces, temperature, the length of the contact zone, and the contact time.

\section{EFFECT OF AUSTENITIZATION TEMPERATURE}

The grain size, secondary hardness and percentage of retained austenite in the steel HS3-1-1 increase (Table 3) with an increase of austenitization temperature. Moreover, the percentage of retained austenite increases greatly in the case of the austenitization temperature of $1160^{\circ} \mathrm{C}$ and above this temperature, and for the retained austenite removal in heat treatment process there is a necessity to increase the number of tempering processes. To avoid this, the austenitization temperature should be limited to $1140^{\circ} \mathrm{C}$. The presented data also show that the austenitization temperature of cutting tools cannot be $1080^{\circ} \mathrm{C}$ because the secondary hardness is then less than 63 HRC.

The effect of the austenitization temperature on the impact resistance, the flexural strength and hardness of HS3-1-1 steel is shown in table 4. It can be concluded that the austenitization temperature of $1180^{\circ} \mathrm{C}$ is too high due to too big grain size and the temperature of $1080^{\circ} \mathrm{C}$ is too low, because the hardness after tempering for the 4 hours at $630^{\circ} \mathrm{C}$ is only $50.5 \mathrm{HRC}$. 
Table 3. Hardness, grain size of retained austenite and the percentage of secondary austenite in HS3-1-1 steel depending on the austenitization temperature

\begin{tabular}{|c|c|c|c|c|c|c|}
\hline \multirow{2}{*}{$\begin{array}{c}\text { Austenitization } \\
\text { temperature } \\
{ }^{\circ} \mathrm{C}\end{array}$} & \multirow{2}{*}{$\begin{array}{c}\text { Hardness after } \\
\text { hardening, } \\
\text { HRC }\end{array}$} & \multirow{2}{*}{$\begin{array}{c}\text { Grain size, } \\
\mu \mathrm{m}\end{array}$} & \multicolumn{2}{|c|}{$\begin{array}{c}\text { Twofold tempering } \\
\text { 1h - 5500C }\end{array}$} & \multicolumn{2}{|c|}{$\begin{array}{c}\text { Threefold tempering } \\
\text { 1h }-5500 \mathrm{C}\end{array}$} \\
\cline { 5 - 7 } & & & $\begin{array}{c}\text { Hardness, } \\
\text { HRC }\end{array}$ & $\begin{array}{c}\text { Retained auste- } \\
\text { nite, } \%\end{array}$ & $\begin{array}{c}\text { Hardness, } \\
\text { HRC }\end{array}$ & $\begin{array}{c}\text { Retained auste- } \\
\text { nite, } \%\end{array}$ \\
\hline 1080 & 61 & 13 & 61 & 15 & 62 & - \\
\hline 1100 & 61 & $13-12$ & 62.3 & 16.5 & 62 & - \\
\hline 1120 & 60 & $12-11$ & 62 & 18 & 62.5 & 2 \\
\hline 1140 & 59 & $11-10$ & 63 & 19.5 & 63 & 4 \\
\hline 1160 & 57 & 8 & 60 & 21 & 62 & 14.5 \\
\hline 1180 & 53 & $8-7$ & 55.3 & 30 & 61.5 & 21 \\
\hline
\end{tabular}

Table 4. Effect of the austenitization temperature on the mechanical properties of HS3-1-1steel

\begin{tabular}{|c|c|c|c|}
\hline $\begin{array}{c}\text { Austenitization temperature } \\
\mathrm{Ta}^{\circ} \mathrm{C}\end{array}$ & $\begin{array}{c}\text { Hardness after tempering } \\
\left(4 \mathrm{~h} \text { at } 630^{\circ} \mathrm{C}\right), \mathrm{HRC}\end{array}$ & $\begin{array}{c}\text { Flexural strength } \mathrm{R}_{\mathrm{g}} \\
\mathrm{MPa}\end{array}$ & $\begin{array}{c}\text { Impact resistance } \\
\mathrm{U}, \mathrm{J} / \mathrm{m}^{2}\end{array}$ \\
\hline 1080 & 50.5 & 5580 & $4.6 \times 10^{5}$ \\
\hline 1100 & 50.5 & 3350 & $4.2 \times 10^{5}$ \\
\hline 1120 & 55.5 & 3020 & $4.0 \times 10^{5}$ \\
\hline 1140 & 56.5 & 2840 & $3.6 \times 10^{5}$ \\
\hline 1160 & 56.5 & 2650 & $3.2 \times 10^{5}$ \\
\hline 1180 & 57 & 2300 & $2.5 \times 10^{5}$ \\
\hline
\end{tabular}

The estimation of cutting ability of the tools made of high-speed steel vs. the austenitic temperature requires to consider how the cutting ability affects the technological properties of steel, of which the most important is grindability. Therefore it appears advisable to clarify the effect of heat treatment parameters on the cutting ability coefficient of the tested steel as also to determine how the austenitizing temperature affects the microstructural changes in the material occurring during the grinding. The properties of the workpiece material largely depend on their chemical composition, the wear of the tool material and the applied grinding parameters. To analyze mentioned phenomena, an analysis of the phase composition of the HS3-1-1 steel depending on the heat treatment parameters and an analysis of the chemical composition of the carbide isolates were determined. Table 5 presents the results of the effect of the austenitization temperature on the grinding ratio of HS3-1-1 steel. The value of this ratio is evaluated using the formula:

$$
K=Q_{m} / P_{y}
$$

where: $Q_{m}$ - the amount of material, which is

taken off in time unit,

$P_{y}$ - inverted grinding force.

The value of the grinding coefficient over an investigated range of the austenitization tem- peratures is almost constant. The value of the grinding coefficient depends more on a number of tempering than the austenitization temperature. After the third tempering the process of dispersion hardening intensifies and more carbides release. Intensification of the release of carbides results in decreasing the grinding ratio. In the case of austenitization at a temperature of $1160^{\circ} \mathrm{C}$ even after threefold tempering in the steel microstructure retains of $20 \%$ of retained austenite, and thus the value of grinding ratio remains almost constant.

Table 6 presents the chemical composition of selected elements in carbide isolates of HS31-1 steel. The diffraction analyses confirmed that M7C3 and M6C carbides dissolve during austenitization. This conclusion results from the fact

Table 5. Grinding ratio HS3-1- 1 steel vs. austenitization temperature

\begin{tabular}{|c|c|c|}
\hline \multirow{2}{*}{$\begin{array}{c}\text { Austenitization } \\
\text { temperature Ta, }{ }^{\circ} \mathrm{C}\end{array}$} & \multicolumn{2}{|c|}{ Grinding ratio } \\
\cline { 2 - 3 } & $\begin{array}{c}\text { Twofold } \\
\text { tempering }\end{array}$ & $\begin{array}{c}\text { Threefold } \\
\text { tempering }\end{array}$ \\
\hline 1080 & 4.49 & 3.64 \\
\hline 1100 & 4.25 & 3.58 \\
\hline 1120 & 4.16 & 3.62 \\
\hline 1140 & 4.30 & 3.51 \\
\hline 1160 & 4.09 & 3.96 \\
\hline
\end{tabular}


Table 6. The chemical composition of the carbide isolate of HS3-1-1 steel

\begin{tabular}{|l|c|c|c|c|c|c|c|}
\hline \multicolumn{1}{|c}{ Heat treatment of isolate } & \multicolumn{5}{c|}{ Content of selected elements in isolate, \% wt. } \\
\cline { 2 - 8 } & $\mathrm{Fe}$ & $\mathrm{Mn}$ & $\mathrm{Cr}$ & $\mathrm{W}$ & $\mathrm{Mo}$ & $\mathrm{V}$ & $\mathrm{Si}$ \\
\hline Soft annealing & 34.89 & 0.74 & 21.67 & 16.26 & 6.33 & 9.14 & 0.98 \\
\hline Austenitization at $1080^{\circ} \mathrm{C}$ & 22.77 & 0.28 & 14.33 & 12.86 & 5.10 & 10.81 & 6.94 \\
\hline Austenitization at $1120^{\circ} \mathrm{C}$ & 12.09 & 0.13 & 7.44 & 10.00 & 3.93 & 10.75 & 10.60 \\
\hline Austenitization at $1150^{\circ} \mathrm{C}$ & 6.23 & 0.07 & 4.84 & 9.41 & 3.55 & 10.42 & 9.72 \\
\hline Austenitization at $1120^{\circ} \mathrm{C}$ and tempering at $550^{\circ} \mathrm{C}(2 \mathrm{~h})$ & 16.00 & 0.23 & 10.48 & 14.65 & 5.71 & 10.70 & 6.08 \\
\hline $\begin{array}{l}\text { Austenitization at } 1393^{\circ} \mathrm{C} \text { and tempearing at } 550^{\circ} \mathrm{C}(2 \mathrm{~h}), \\
\text { and tempering at } 550^{\circ} \mathrm{C}(4 \mathrm{~h})\end{array}$ & 89.81 & 0.84 & 17.79 & 13.13 & 5.75 & 10.46 & 1.02 \\
\hline
\end{tabular}

that the $\mathrm{Cr}, \mathrm{Fe}, \mathrm{W}$ and Mo pass from the carbides into the matrix [10].

Relatively little volume of vanadium passes into the matrix, which indicates no dissolution of the $\mathrm{MC}$ carbide in matrix. The investigations also show the influence of tempering conditions on the volume of carbide phases in HS3-1-1 steel. The increase of the carbides content after tempering proves the occurrence of separation and coarsening processes of carbides [17]. The percentage of the silicon carbide increases with an increase of the austenitization temperature, but during tempering the percentage of silicon in carbides decreases to the content of silicon in carbides after the annealing.

\section{WEAR OF PULL BROACH}

Based on the obtained data of pull broach wear the figures presented the influence of the number sharpening on the mean wear of teeth and mean standard deviation for the rough teeth (fig. 5) and keyway broach front pilot (fig. 6). The analyses were carried out for the same number of parts machined. The results show that both value of wear

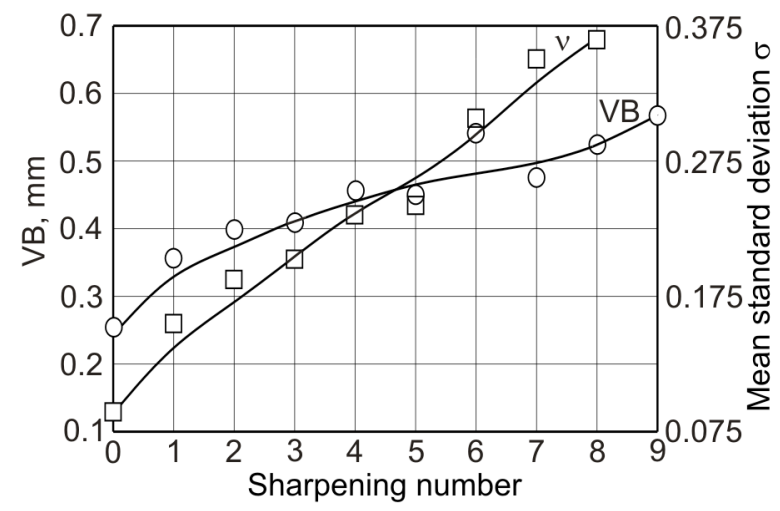

Fig. 5. Effect of a sharpening number on the maintenance parameters of rough teeth of keyway broach of broach teeth and the mean standard deviation increase with an increase of the number of sharpening. The coefficient of variance also increases with an increase in the number of sharpening, what indicates the reduction of the operational reliability of the keyway broach.

\section{CONCLUSIONS}

Efficient selection of the chemical constitution makes it possible to improve the grinding properties of low-alloy high-speed steels. Based on the value of the grinding ratio, it can be concluded that among the tested steels HS2-5-2 steel has the highest grindability. This is due to the low content of vanadium carbides in this steel. The value of the grinding ratio depends on grinding forces, whose values have an impact on the grinding temperature and consequently tool wear.

The value of austenitization temperature decided on mechanical properties of the high-speed steel. It can be concluded that the austenitization temperature of $\mathrm{HS} 3-1-1$ equal to $1180^{\circ} \mathrm{C}$ is too high due to too big grain size and the temparature of $1080^{\circ} \mathrm{C}$ is too low, because the hardness after

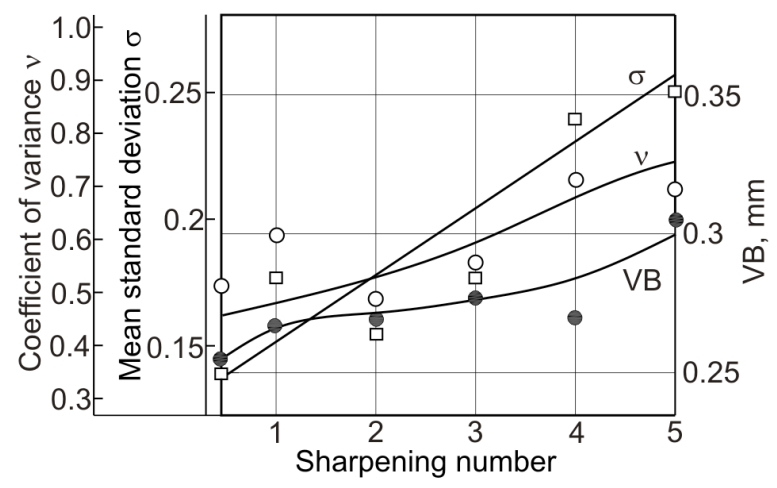

Fig. 6. Effect of a sharpening number on the maintenance parameters of teeth of keyway broach front pilot 
tempering for the 4 hours at $630^{\circ} \mathrm{C}$ is only 50.5 HRC. The grain size, secondary hardness and percentage of retained austenite in the steel HS31-1 increase with the increase of austenitization temperature. Furthermore, the investigations also show the influence of tempering conditions on the volume of carbide phases in HS3-1-1 steel.

\section{REFERENCES}

1. Borkowski J.: Wear and Durability of Grinding Wheels. PWN Warszawa 1990.

2. Davim J.P.: Machining of metal matrix composites. Springer-Verlag London 2012.

3. Dobrzański L.A.: Podstawy nauki o materiałach i metaloznawstwo. Materiały inżynierskie z podstawami projektowania materiałowego. WNT Warszawa 2002.

4. Dolinšek B., Šuštaršič J., Kopač J.: Wear mechanisms of cutting tools in high-speed cutting processes. Wear, 250, 2001, 349-356.

5. El-Rakayby A.M., Mills B.: On the microstructure and mechanical properties of high-speed steels. Journal of Materials Science, 23, 2013, 4340-4344.

6. Jaworski J., Kluz R., Trzepieciński T.: Operational tests of wear dynamics of drills made of low-alloy high-speed HS2-5-1 steel. Eksploatacja i Niezawodnosc - Maintenance and Reliability, 18, 2016, 271-277.

7. Jaworski J., Trzepieciński T.: Research on durability of the turning tools made of low-alloy highspeed steel. Kovove Materialy-Metallic Materials, 54, 2016, 17-25.

8. Józwik J., Mika D.: Diagnostics of workpiece surface condition based on cutting tool vibrations during machining. Advances in Science and Technology Research Journal, 9, 2015, 57-65.
9. Lipiński D., Kacalak W., Tandecka K.: Zastosowanie systemu skanowania przestrzennego do oceny zużycia narzędzi ściernych. Pomiary, Automatyka, Kontrola, 59, 2013, 1227-1230.

10. Llewellyn D.T.: Steels: Metallurgy and Applications. Butterworth-Heinemann Oxford 1992.

11. Mucha J., Jaworski J.: The tool surface wear during the silicon steel sheets blanking process. Eksploatacja i Niezawodnosc - Maintenance and Reliability, 18, 2016, 332-342.

12. Natapov B.E., Tishaev S.I.: Properties and rational use of low-alloy high-speed steels. Strength Properties, 30, 1988, 381-386.

13. Sadílek M., Kratochvíl J., Petrů J., Čep R., Zlámal T., Stančeková D.: Cutting tool wear monitoring with the use of impedance layers. Tehnicki vjesnikTechnical Gazette, 21, 2014, 639-644.

14. Sharma V.S., Sharma S.K., Sharma A.K.: Cutting tool wear estimation for turning. Journal of Intelligent Manufacturing, 19, 2008, 99-108.

15. Sinopalnikow W.A., Grigoriew S.N.: Reliability and Diagnosis of Technological Systems. MGU Stankin Moscov 2003.

16. Wartacz A., Świć A., Zubrzycki J.: Zużycie ostrza narzędzia, a zmiana parametrów toczenia w kolejnych zabiegach. Eksploatacja i Niezawodnosc Maintenance and Reliability, 24, 2004, 58-61.

17. Xu L.Q., Zhang D.T., Liu Y.C., Ning B.Q., Qiao Z.X., Yan Z.S., Li H.J.: Precipitation behavior and martensite lath coarsening during tempering of $\mathrm{T} /$ P92 ferritic heat-resistant steel. International Journal of Minerals, Metallurgy, and Materials, 21, 2014, 438-447.

18. Zagórski I., Kuczmaszewski J.: The study of cutting forces and their amplitudes during high-speed dry milling magnesium alloys. Advances in Science and Technology Research Journal, 7, 2013, 61-66. 